\title{
The calculation of greenhouse gas emissions of a family and projections for emission reduction
}

\author{
Mehmet Mustafa Yatarkalkmaz (D) \\ Turkish Standards Institution, Ankara, Turkey, myatar@tse.org.tr \\ Mustafa Bahadır Özdemir (D) \\ Department of Energy Systems Engineering, Gazi University, Ankara, Turkey, mbozdemir@gazi.edu.tr \\ Arrived: 16.05.2019 Accepted: 17.07.2019 Published: 30.09.2019

\begin{abstract}
The article shows how to calculate greenhouse gas emissions of a family and emission reduction activities according to IPCC documents and ISO 14064-1 standards. In this study, direct and energy indirect emissions in 2017 are calculated. Then, within the scope of emission reduction activities, PV system installation, boiler exchange and led conversion are projected. As a result of the calculations, the total emission of the family is found to be 5,331 tons $\mathrm{CO}_{2}$-Eq. $84.1 \%$ of the total emission is direct emissions that is 4,484 tons $\mathrm{CO}_{2}$-Eq. The remaining $15.9 \%$ is energy indirect emission that is 0,847 tons $\mathrm{CO}_{2}$-Eq. Besides, 0,407 tons $\mathrm{CO}_{2}$-Eq from direct emission and 0,464 tons $\mathrm{CO}_{2}$-Eq from energy indirect emission are reduced. With the help of simple projections, we can reduce direct emissions by approximately $8 \%$, while energy indirect emissions by about 55\%. It is thought that the study will guide the calculation of greenhouse gas emissions and will also help those who wish to reduce greenhouse gas emissions.
\end{abstract}

Keywords: Greenhouse gas (GHG) emission, ISO 14064-1, Emission reduction strategies, Energy consumption, Energy efficiency, Carbon footprint

Cite this paper as:

Yatarkalkmaz, M.M., Özdemir, M.B. The calculation of greenhouse gas emissions of a family and projections for emission reduction, Journal of Energy Systems 3(3);(2019); 96-110, DOI: 10.30521/jes.566516

(C) 2019 Published by peer-reviewed open access scientific journal, JES at DergiPark (www.dergipark.gov.tr/jes)

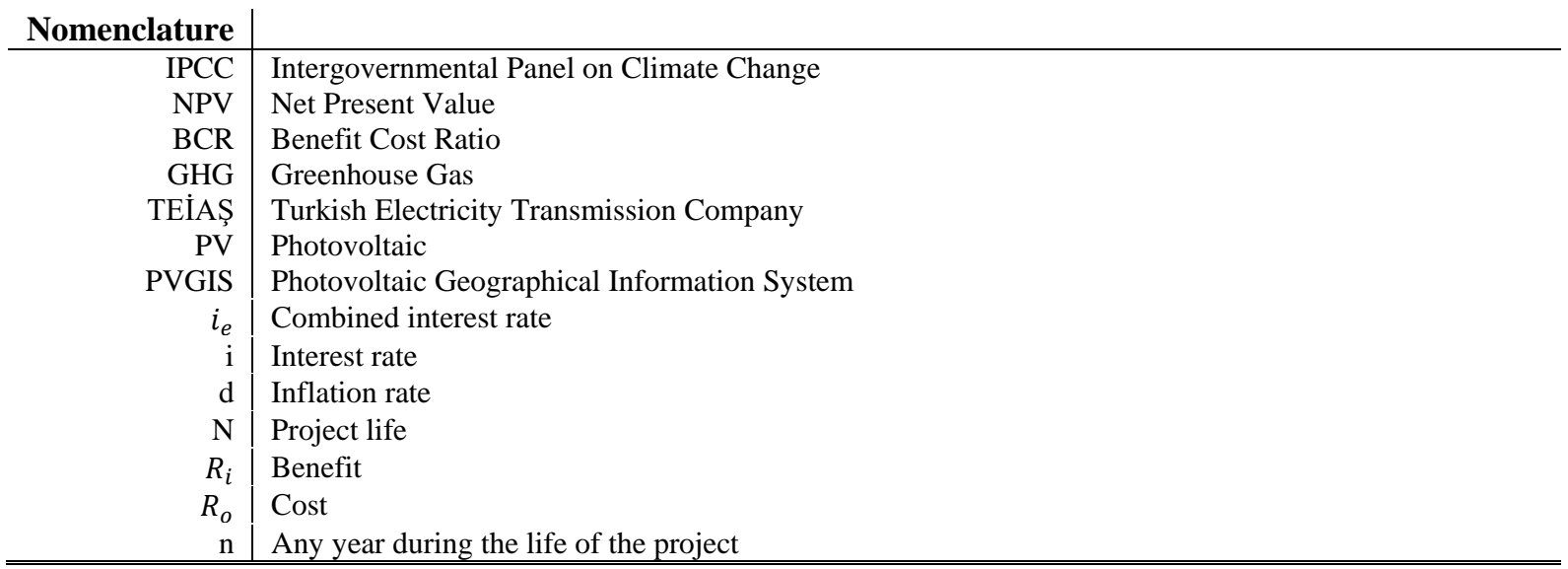




\section{INTRODUCTION}

The atmosphere absorbs, owing to the gases it contains, some of the solar radiation reflected from the earth, and it cools down by giving some of it back. However, some of this radiation is absorbed by the greenhouse gases in the atmosphere, which causes the atmosphere and the Earth's surface to warm up, without spreading into space. If the atmosphere did not have this characteristic, the earth's average temperature of $15^{\circ} \mathrm{C}$ would fall to $-18{ }^{\circ} \mathrm{C}[1]$. Moreover, the increased concentration of carbon dioxide, chlorofluorocarbons, methane and nitrogen oxides in the atmosphere creates a greenhouse effect. This is also the main cause of global climate change. According to the IPCC, the average global temperature of the compound in the land and ocean increased by $0.85^{\circ} \mathrm{C}$ between $1880-2012$ [2]. Because of the increase in the average temperature on a global scale, the glaciers have been rapidly melting and the sea level has been rising, the evaporation and precipitation regimes have been changing, and thus, drought and floods have been increasing. The reduction of water resources, one of the most important consequences of global warming and climate change, has reached to the extent of preventing sustainable living and environmental conditions [3].

The main gases that cause greenhouse effect are carbon dioxide $\left(\mathrm{CO}_{2}\right)$, methane $\left(\mathrm{CH}_{4}\right)$, diazot monoxide $\left(\mathrm{N}_{2} \mathrm{O}\right)$, chlorofluoro carbons (CFC) and fluorinated gases. Some of these gases can be formed mostly through human activities and through natural means, and their concentration in the atmosphere has increased since 1750 [2]. The concentrations of $\mathrm{CO}_{2}, \mathrm{CH}_{4}, \mathrm{~N}_{2} \mathrm{O}$ gases increased at the rate of $40 \%, 150 \%$ and $20 \%$ and by levels of $391 \mathrm{ppm}, 1803 \mathrm{ppb}$ and $324 \mathrm{ppb}$ respectively from their pre-industrial levels to those in 2011[2]. In view of such drastic rise, many international discussions and studies on greenhouse gas emissions have been initiated. Having started in the First World Climate Conference in 1979, the works continued with the Intergovernmental Panel on Climate Change in 1988. In 1992, the United Nations Conference on Environment and Development was convened and the United Nations Framework Convention on Climate Change was signed and adopted in 1994. With the Kyoto Protocol signed by 160 countries in 1997, measurement and calculation of these emissions, studies to be carried out in this regard and measures to be taken are considered as priority, and accordingly, the protocol has been implemented in 2005. In 2015, the 21st Climate Change Conference was convened in Paris and the Treaty of Paris was signed, and the inurement of the Treaty of Paris became final in 2016 [4].

In addition to the studies and discussions, ISO 14064-1, ISO 14064-2, ISO 14064-3 standards have been issued by the relevant Technical Committees of the International Standards Organization to create a system for tracking greenhouse gas emissions. The ISO 14064-1 standard covers the principles and requirements for calculating and reporting of greenhouse gas emissions and removals at the establishment level [5]. The ISO 14064-2 standard provides guidance for calculating, monitoring and reporting activities that are expected to lead to improvements in greenhouse gas emissions reductions and removal [6]. The ISO 14064-3 standard covers the principles and requirements for those conducting or verifying greenhouse gas declarations and governing them [7].

Although the studies on greenhouse gas emissions in Turkey are new, a greenhouse gas emission inventory has been held since 1990. The greenhouse gas emissions were 210.7 million tons of $\mathrm{CO}_{2}$-eq in 1990 while it was 494.1 million tons of $\mathrm{CO}_{2}$-eq and increased by $135.4 \%$ in 2016 [8]. The tons of $\mathrm{CO}_{2}$-eq per capita in 1990 was calculated as 3.8 tons/person and this value was calculated as 6.3 tons/person in 2016 [9]. In the Intended Nationally Determined Contribution of the Republic of Turkey, while the reference scenario of 2030 expects an increase in total emissions by $467 \%$ compared to 1990 , reaching 1175 million tons $\mathrm{CO}_{2}$-eq, mitigation scenario of 2030 projects an increase in total emissions by $348 \%$ compared to 1990 , reaching 929 million tons $\mathrm{CO}_{2}$-eq. Accordingly, a reduction in emissions by $21 \%$ are estimated [10]. 
Increasing population, industrialization and rapid urbanization will increase energy demand, and therefore, will increase emissions considering the 2030 greenhouse gas emission scenario. While fossil sources provide most of the current energy demand, the scenarios of 2040 predict that fossil resources will provide approximately $75.8 \%$ of the energy demand, and that the percentage of energy demand to be met by other sources will be at the rate of $8.7 \%$ for bioenergy, of $7.7 \%$ for other renewable sources, of $5.4 \%$ for nuclear and of $2.8 \%$ for hydraulic [11]. In view of external energy dependency of Turkey, using renewable energy sources and improving energy efficiency are of vital importance for Turkey to reduce both external dependence and carbon emissions.

The literature review is performed on the calculation of greenhouse gas emissions and carbon footprint. One study calculates the carbon footprint generated by the tourist activities in Barcelona, which more than 30 million guests visit every year. The analysis reveals that total emission of Barcelona tourist activity is approximately 9.6 million tons $\mathrm{CO}_{2}$-eq/year, which represents an emission of $96.93 \mathrm{~kg} \mathrm{CO}_{2}-$ $\mathrm{eq} / \mathrm{visitor}$ per day. Besides, the average carbon footprint of a tourist is $111.6 \mathrm{~kg} \mathrm{CO}_{2}$-eq/day and $43.0 \mathrm{~kg}$ $\mathrm{CO}_{2}$-eq/day for a day-tripper [12]. Another study shows the emission between 2006 and 2010 in the Province of Siena. While the significant reduction of GHG emission released to the atmosphere is about $\% 81.3$, the net emission is $449 \mathrm{Gg} \mathrm{CO}_{2}$-eq in 2006 and $84 \mathrm{Gg} \mathrm{CO}_{2}$-eq in 2010 [13]. In a study conducted in Israel, greenhouse gas emissions are calculated and direct emissions by sectors increased by $8.46 \%$ in 2012 compared to the previous year, while energy indirect emissions increased by 53.29\% [14]. The GHG emission results of 5 wineries, one wine cellar and 9 grape producers in Germany are between 0.753 and $1.069 \mathrm{~kg} \mathrm{CO}_{2}$-eq/bottle of wine in the other study [15]. In another study, a greenhouse gas emission calculation is made for a tannery company in Turkey, direct emission is 575.7 tons $\mathrm{CO}_{2}$-eq, energy indirect emission was 437.2 tons $\mathrm{CO}_{2}$-eq, and other indirect emission is 836.4 tons $\mathrm{CO}_{2}$-eq [16]. In a study conducted at Kahramanmaraş Airport, emissions from flights in 2016 are calculated according to aircraft types [17]. Another study calculates Carbon footprint of Birla Institute of Technology and Science Pilani, Pilani campus, India according to ISO 14064 standards, and compare the results with other universities [18]. In this study, the greenhouse gas emissions of wine producers in Siena are calculated and compared with the emission amount of producers in other continents and countries [19]. In another study conducted in Siena, greenhouse gas emissions between 2008-2011 are calculated and the changes in emission rates were examined. While the emission in 2009 decrease by $5,36 \%$ compared to 2008 , the 2010 emission increase by $20,59 \%$ compared to 2008 and the emission of 2011 decrease by $37,96 \%[20]$.

The aim of this study is to calculate the annual greenhouse gas emissions of a family through classifying them as direct, energy indirect and other indirect emissions as specified in the ISO 14064-1 standard and to emphasize the importance of carbon emission reduction and energy efficiency. Besides, it aims to compare and contrast the pre and post-recovery levels according to the emission classes through analyzing greenhouse gas emission reduction projection with improvement actions and economic analysis of these actions. Thanks to the study, the emissions that cause the greenhouse gas effect, which is a global problem, will be examined and everyone will be able to calculate how much it causes. The work will also show how much emissions can be reduced by making simple changes and saving. The main purpose of the study is to create awareness and draw attention to greenhouse gas emissions.

\section{METHODOLOGY}

Greenhouse gas emissions are divided into three classes according to EN ISO 14064-1. First, direct emissions are greenhouse gas emissions from greenhouse gas sources owned or controlled by an organization. Secondly, energy indirect emissions are greenhouse gas emissions generated by the external supply of electricity, heat or steam consumed by an organization. Finally, other indirect 
emissions are greenhouse gas emissions from greenhouse gas sources owned or controlled by other organizations because of the activities of an organization [5].

In general, emissions of each greenhouse gas from the sources are calculated by multiplying fuel consumption by the corresponding emission factor. In the study, IPCC 2006 Tier 1 method is applied to calculate direct emissions. In order to calculate the energy indirect emissions, it is necessary to calculate the electrical emission factor. Turkey's specific electricity emission factor is calculated using TEIAS data according to IPCC Tier 2 method.

Within the scope of greenhouse gas reduction activities, the amount of electricity that can be produced by the modules in a specified location and the amount of radiation falling into the location is obtained by the application of PVGIS 5. Besides, net present value method and benefit cost ratio method are used in economic analysis.

\subsection{Calculation of GHG Emission}

\subsubsection{TIER 1 method}

In Tier 1 method, emissions of $\mathrm{CO}_{2}, \mathrm{CH}_{4}$ and $\mathrm{N}_{2} \mathrm{O}$ are calculated by multiplying the amount of fuel consumed and the emission factor [21]. The following equation is used:

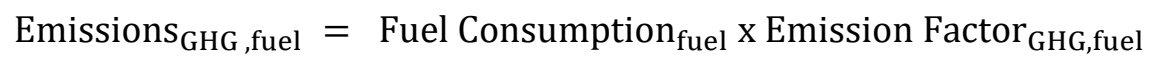

where, Emissions ${ }_{\mathrm{GHG}}$,fuel is emissions of a given GHG by type of fuel (kg GHG), Fuel Consumption fuel $_{\text {f }}$ is amount of fuel combusted (TJ), Emission Factor $_{\mathrm{GHG}, \text { fuel }}$ is default emission factor of a given GHG by type of fuel (kg gas/TJ). For $\mathrm{CO}_{2}$, it includes the carbon oxidation factor, assumed to be 1 .

Moreover, $\mathrm{CO}_{2}, \mathrm{CH}_{4}, \mathrm{~N}_{2} \mathrm{O}$ and other gases are converted to tons $\mathrm{CO}_{2}$-Eq by using the last updated global warming potential values. To calculate the total emissions by gas from the source, the emissions as calculated in Equation 1 are summed over all fuels [21]:

$$
\text { Emissions }_{\mathrm{GHG}}=\sum_{\text {fuels }} \text { Emissions }_{\mathrm{GHG}, \text { fuel }}
$$

\subsubsection{TIER 2 method}

Under Tier 2, the Tier 1 default emission factors in Equation 1 are replaced by country-specific emission factors. Country-specific emission factors can be developed by taking into account country-specific data such as carbon contents of the fuels used, carbon oxidation factors, fuel quality and the state of technological development. When calculating country-specific emission factor, the amount of emissions released according to the types of fuels used is calculated. In other words, the total emissions are then divided by the amount of electricity or heat or steam supplied [21].

\subsection{Power Generation}

PVGIS produces calculations of solar radiation and photovoltaic system energy production. With the help of the program, the total amount of radiation in the selected location and the amount of electricity that can be obtained from the PV systems with the installed capacity are calculated. The interface of the program is shown in Figure 1 [22]. 


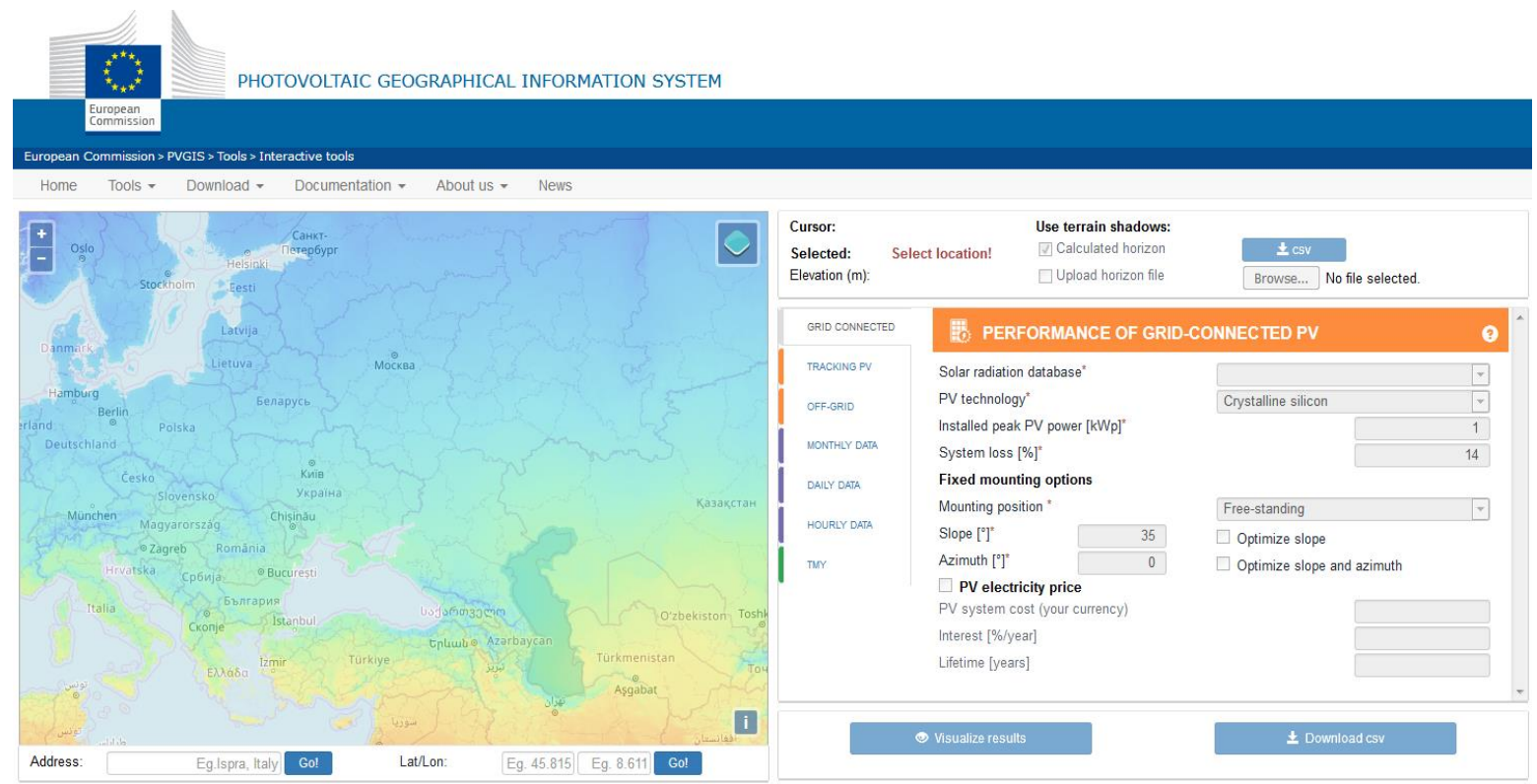

Figure 1. PVGIS interface [22]

Location is determined by selecting location from map or entering address information or entering latitude and longitude information before entering relevant information about PV systems.

Getting started with the program, the grid-connected tab is selected from the program menu. Solar radiation database selection is made to calculate the amount of annual radiation. PVGIS-CMSAF database that cover Europe, Africa and parts of South America is more suitable in irradiation calculation for Turkey. Then PV system type is selected to be used in calculations. For calculation of electricity, installed peak PV power, which is the total power of PV system, is entered in $\mathrm{kWp}$. The estimated system losses are all the losses in the system.

After entering the system information, the positioning information of the modules is entered. In PVGIS, there are two mounting position possibilities: freestanding modules, which are mounted on a rack with air flowing freely behind the modules; and building-integrated modules, which are completely built into the structure of the wall or roof of a building, with no air movement behind the modules. Subsequently, slope of PV modules, which is the angle of the PV modules from the horizontal plane, and azimuth of PV modules, which is the angle of the PV modules relative to the direction due south, are entered. If optimizing slope and/or azimuth is chosen, PVGIS will calculate the slope of the PV modules that gives the highest energy output for the whole year. PVGIS can also calculate the optimum azimuth if desired. These options assume that the slope and azimuth angles stay fixed for the entire year.

\subsection{Economic Analysis}

The net present value method is used to make an economic analysis of the system. The difference between the present value of the cash benefit that will be provided during the life of the system and the present value of the expenses such as investment and maintenance of the system is called as the net present value method. With this method, the combined interest rate is used to make the economic analysis of the system.

$$
\mathrm{i}_{\mathrm{e}}=(1+\mathrm{i}) *(1+\mathrm{d})-1
$$

To carry out the analysis with the help of the calculated combined interest rate, the current value is calculated with the help of the benefits and costs Eq. 4 and the difference between the total benefits and the total costs is calculated with the help of Eq. 5 [23]. 


$$
\mathrm{NPV}=\text { Benefit }- \text { Cost }
$$

$$
\mathrm{NPV}=\sum_{0}^{\mathrm{N}} \frac{\mathrm{R}_{\mathrm{i}_{\mathrm{n}}}}{\left(1+\mathrm{i}_{\mathrm{e}}\right)^{\mathrm{n}}}-\sum_{0}^{\mathrm{N}} \frac{\mathrm{R}_{\mathrm{o}_{\mathrm{n}}}}{\left(1+\mathrm{i}_{\mathrm{e}}\right)^{\mathrm{n}}}
$$

In the benefit / cost ratio method, as in the same NPV method, there are totals of the present values of the benefits and costs to be generated by the project and dividing the sum of the present values of the benefits by the totals of the current values of the costs give the benefit / cost ratio that is calculated with the help of Eq. 6 and 7 [23].

$$
\begin{gathered}
\text { BCR }=\frac{\text { Benefit }}{\text { Cost }} \\
\text { BCR }=\sum_{0}^{N} \frac{\mathrm{R}_{\mathrm{i}_{\mathrm{n}}}}{\left(1+\mathrm{i}_{\mathrm{e}}\right)^{\mathrm{n}}} / \sum_{0}^{\mathrm{N}} \frac{\mathrm{R}_{\mathrm{o}_{\mathrm{n}}}}{\left(1+\mathrm{i}_{\mathrm{e}}\right)^{\mathrm{n}}}
\end{gathered}
$$

\section{GREENHOUSE GAS INVENTORY}

Direct (scope 1) and energy indirect (scope 2) emission sources of the family are discussed in 2017. Other indirect emission (scope 3) is not taken into account. The direct emission sources of the family whose data are used in the calculation are natural gas used for heating purposes, gasoline consumption of vehicles, refrigerant leaks. Energy indirect emission source are steam and electricity supplied. However, the only energy indirect emission of the family is electricity.

\subsection{Direct Emission Inventory}

In the calculation, the total annual consumption amount is multiplied by $\mathrm{CO}_{2}, \mathrm{CH}_{4}$ and $\mathrm{N}_{2} \mathrm{O}$ coefficients and the individual emissions are obtained. Then, each gas is multiplied by the global warming potential coefficient to obtain the total $\mathrm{CO}_{2}$-Eq. Likewise, the emission of the refrigerant gases is obtained by multiplying the total gas capacity of the device with the leakage rate. Subsequently, the total $\mathrm{CO}_{2}-\mathrm{Eq}$ is obtained by multiplying the global warming potential. In the last stage, direct greenhouse gas emissions are collected and scope 1 greenhouse gas emissions are obtained. For the direct emission inventory, the bills of the natural gas consumed during 2017 and the vehicle fuel slips are investigated. For emissions from gas leakage, label data of devices and leakage rates in IPCC documents are taken into account. In 2017, fuel consumed is given in Table 1 and refrigerant fluid capacities and leakage rate are given in Table 2. Also, the default emission factors are given in Table 3, and global warming potential, which is a measure of how much heat a greenhouse gas traps in the atmosphere up to a specific time horizon relative to carbon dioxide, is given in Table 4. 
Table 1. Consumed fuels in 2017

\begin{tabular}{lcc}
\hline Months & Natural Gas (sm3) & Gasoline (lt) \\
\hline January & 272,365 & 55 \\
February & 299,155 & 52 \\
March & 201,818 & 54 \\
April & 156,275 & 67 \\
May & 103,588 & 65 \\
June & 31,255 & 72 \\
July & 6,251 & 85 \\
August & 6,251 & 99 \\
September & 7,144 & 135 \\
October & 10,716 & 70 \\
November & 50,901 & 53 \\
December & 122,341 & 56 \\
Total & 1268,06 & 863 \\
\hline
\end{tabular}

In the IPCC documents, the leakage rate for water dispenser and refrigerator is $0.1 \%$, whereas this rate is $1 \%$ for air conditioner. When the total gas capacity and leakage ratio of the device are multiplied, the total annual leakage rate is obtained. Direct emissions include emissions from stationary combustion, mobile combustion and gas leaks. While the natural gas consumed for heating and cooking purposes is evaluated within the scope of stationary combustion, the fuels consumed by the vehicles are evaluated within the scope of mobile combustion. While natural gas used in heating is evaluated in commercial category, the sources used in electricity generation are evaluated in energy category.

Table 2. Refrigerant inventory [24]

\begin{tabular}{lllll}
\hline Equipment & Fluid Type & Capacity (gr) & Leakage Rate (\%) & Leakage Quantity (kg) \\
\hline Water Dispenser & R134A & 33 & 0,1 & 0,000033 \\
Refrigerator & R600A & 65 & 0,1 & 0,000065 \\
Air Conditioner & R22 & 1550 & 1 & 0,0155 \\
\hline
\end{tabular}

Table 3. Default emission factors of direct emissions [21], [25]

\begin{tabular}{llccc}
\hline \multirow{2}{*}{ Fuel Type } & \multirow{2}{*}{ Category } & \multicolumn{3}{c}{ Default emission factors $(\mathrm{kg} / \mathrm{TJ})$} \\
\cline { 3 - 5 } & & $\mathrm{CO}_{2}$ & $\mathrm{CH}_{4}$ & $\mathrm{~N}_{2} \mathrm{O}$ \\
\hline Natural Gas & Commercial & 56.100 & 5 & 0,1 \\
Gasoline & Road Transport & 69.300 & 25 & 8 \\
Anthracite & Energy Industries & 96.100 & 1 & 1,5 \\
Lignite & Energy Industries & 101.000 & 1 & 1,5 \\
Fuel-Oil & Energy Industries & 77.400 & 3 & 0,6 \\
Diesel & Energy Industries & 74.100 & 3 & 0,6 \\
Natural Gas & Energy Industries & 56.100 & 1 & 0,1 \\
\hline
\end{tabular}

Table 4. Global warming potential [26]

\begin{tabular}{ll}
\hline Greenhouse Gas Type & Global Warming Potential \\
\hline $\mathrm{CO}_{2}$ & 1 \\
$\mathrm{CH}_{4}$ & 28 \\
$\mathrm{~N}_{2} \mathrm{O}$ & 265 \\
$\mathrm{R} 600 \mathrm{~A}$ & 3 \\
$\mathrm{R} 134 \mathrm{~A}$ & 1300 \\
$\mathrm{R} 22$ & 1760 \\
\hline
\end{tabular}




\subsection{Energy Indirect Emission Inventory}

In order to calculate the energy indirect emission amount, the total amount of electricity consumed in 2017 is multiplied by the electricity emission factor. The amount of electricity consumed and electricity emission factor must be known in order to calculate the energy indirect emission. The electricity consumption in 2017 has been analyzed through invoices. Consumption by months are shown in Table 5 .

Table 5. Monthly electricity consumption $(\mathrm{kWh})$

\begin{tabular}{lrrr}
\hline Months & Day (07: 00-18: 00) & Peak (18: 00-23: 00) & Night (23: 00-07: 00) \\
\hline January & 85,707 & 43,859 & 46,572 \\
February & 95,426 & 51,676 & 50,692 \\
March & 56,853 & 35,56 & 37,037 \\
April & 62,354 & 32,803 & 37,395 \\
May & 57,303 & 27,583 & 44,641 \\
June & 34,493 & 18,514 & 32,45 \\
July & 50,792 & 27,253 & 36,769 \\
August & 54,088 & 24,527 & 32,121 \\
September & 57,209 & 26,55 & 37,718 \\
October & 65,782 & 33,671 & 42,985 \\
November & 80,983 & 36,124 & 46,239 \\
December & 100,579 & 43,016 & 49,393 \\
Total & 801,569 & 401,136 & 494,012 \\
\hline
\end{tabular}

The electric emission factor is required to calculate the indirect energy emissions specified in the 140641 standard. 2015, 2016 and 2017 data are used, and weighted average is taken to increase the accuracy of the emission factor and decrease its uncertainty. Total fuel used to generate electricity and calorific value of the fuels in the last three years are used to find the electric emissions factor for Turkey (Table 6). Then, the emissions of the last 3 years are calculated by multiplying the default emission factors and the calorific value of the fuels (Table 7). When calculating the electric emission factor, using the weighted average of the last 3 years data will be more accurate.

Table 6. The amount of fuel consumed and the obtained calorific values in the last 3 years for electricity generation [27-28]

\begin{tabular}{lrrrrrr}
\hline \multirow{2}{*}{ Fuel Type } & \multicolumn{3}{c}{ The Amount of Fuel Used $\left(\mathrm{Ton} / 103 \mathrm{~m}^{3}\right)$} & \multicolumn{3}{c}{ The Total Calorific Value (TCal) } \\
\cline { 2 - 7 } & \multicolumn{1}{c}{2015} & \multicolumn{1}{c}{2016} & \multicolumn{1}{c}{2015} & \multicolumn{1}{c}{2016} & \multicolumn{1}{c}{2017} \\
\hline Anthracite & 16.629 .492 & 19.642 .410 & 21.139 .104 & 95.624 & 112.945 & 119.134 \\
Lignite & 49.940 .131 & 60.213 .772 & 64.412 .257 & 85.417 & 103.496 & 107.247 \\
Fuel-Oil & 516.912 & 526.674 & 317.724 & 5.459 & 5.336 & 3.409 \\
Diesel & 238.388 & 306.393 & 197.219 & 2.493 & 3.235 & 2.102 \\
Natural Gas & 20.914 .868 & 18.954 .093 & 22.954 .854 & 189.010 & 172.078 & 201.863 \\
\hline
\end{tabular}

Table 7. Greenhouse gas emissions of the last 3 years

\begin{tabular}{|c|c|c|c|c|c|c|c|c|c|}
\hline \multirow[t]{2}{*}{ Fuel Type } & \multicolumn{3}{|c|}{$\begin{array}{c}\text { The Emission of } 2015 \text { (Ton } \\
\text { GHG) }\end{array}$} & \multicolumn{3}{|c|}{$\begin{array}{c}\text { The Emission of } 2016 \text { (Ton } \\
\text { GHG) }\end{array}$} & \multicolumn{3}{|c|}{$\begin{array}{l}\text { The Emission of } 2017 \text { (Ton } \\
\text { GHG) }\end{array}$} \\
\hline & $\mathrm{CO}_{2}$ & $\mathrm{CH}_{4}$ & $\mathrm{~N}_{2} \mathrm{O}$ & $\mathrm{CO}_{2}$ & $\mathrm{CH}_{4}$ & $\mathrm{~N}_{2} \mathrm{O}$ & $\mathrm{CO}_{2}$ & $\mathrm{CH}_{4}$ & $\mathrm{~N}_{2} \mathrm{O}$ \\
\hline Anthracite & 38.474 .409 & 400 & 601 & 45.443 .559 & 473 & 709 & 47.933 .908 & 499 & 748 \\
\hline Lignite & 36.120 .220 & 358 & 536 & 43.764 .937 & 433 & 650 & 45.351 .134 & 449 & 674 \\
\hline Fuel-Oil & 1.769 .102 & 69 & 14 & 1.729 .151 & 67 & 13 & 1.104 .832 & 43 & 9 \\
\hline Diesel & 773.358 & 31 & 6 & 1.003 .570 & 41 & 8 & 652.243 & 26 & 5 \\
\hline Natural Gas & 44.394 .668 & 791 & 79 & 40.417 .701 & 720 & 72 & 47.413 .364 & 845 & 85 \\
\hline Total Emission & 121.531 .757 & 1.649 & 1.236 & 132.358 .918 & 1.734 & 1.453 & 142.455 .480 & 1.862 & 1.520 \\
\hline
\end{tabular}

After calculating the emissions, the amount of electricity produced is required to calculate the electricity emission factor. The amount of electricity produced in the past 3 years and the weighted average is given in Table 8. 
Table 8. Net Electricity Production [29]

\begin{tabular}{llll}
\hline Year & 2015 & 2016 & 2017 \\
\hline Net Electricity Production $(\mathrm{GWh})$ & $249.899,53$ & $261.950,80$ & $284.257,52$ \\
Percentage in the Total & $31 \%$ & $33 \%$ & $36 \%$ \\
\hline
\end{tabular}

Finally, each GHG emission is divided by the amount of net electricity produced in the year and the electric emission factor of Turkey is obtained by taking a weighted average of the last 3 years according to the greenhouse type (Table 9).

Table 9. Electric emission factor of Turkey

\begin{tabular}{lll}
\hline $\mathrm{CO}_{2}(\mathrm{~kg} \mathrm{GHG} / \mathrm{GWh})$ & $\mathrm{CH}_{4}(\mathrm{~kg} \mathrm{GHG} / \mathrm{GWh})$ & $\mathrm{N}_{2} \mathrm{O}(\mathrm{kg} \mathrm{GHG} / \mathrm{GWh})$ \\
\hline $497.854,851$ & 6,589 & 5,287 \\
\hline
\end{tabular}

\subsection{Other Indirect Emission Inventory}

Other indirect emissions are not included in the study since it is not possible to examine the consumption values of the greenhouse gas sources which are not under the responsibility of the family under scope 3.

\section{RESULTS and DISCUSSION}

\subsection{GHG Emission Results}

Firstly, emissions of each emission source in terms of greenhouse gas are calculated as indicated in the theoretical analysis. Then, each emission is multiplied by the global warming potential to find the $\mathrm{CO}_{2}-$ Eq. Finally, the emissions are divided according to their scope.

Table 10. GHG emissions

\begin{tabular}{lcccc} 
Emission Source & $\mathrm{CO}_{2}$ (ton) & $\mathrm{CH}_{4}$ (ton) & $\mathrm{N}_{2} \mathrm{O}$ (ton) & $\begin{array}{c}\text { Total Greenhouse } \\
\text { Gas Emissions } \\
\left(\mathrm{Ton} \mathrm{CO}_{2}-\mathrm{Eq}\right)\end{array}$ \\
\hline Direct Emission (Scope 1) & 4,453 & 0,0009 & 0,0002 & 4,484 \\
\hline Natural gas used for heating purposes & 2,457 & 0,0002 & 0,000004 & 2,465 \\
\hline $\begin{array}{l}\text { Emissions from fuel consumption of vehicles } \\
\text { Gasoline }\end{array}$ & 1,914 & 0,0007 & 0,000221 & 1,992 \\
\hline Refrigerant emissions & - & - & - & 0,027 \\
\hline Energy Indirect Emission (Scope 2) & 0,845 & 0,000011 & 0,00001 & 0,847 \\
\hline Emissions from electricity consumption & 0,845 & 0,000011 & 0,00001 & 0,847 \\
\hline Total & 5,297 & 0,0018 & 0,0002 & 5,331 \\
\hline
\end{tabular}

As shown in Table 10, direct emissions are 4,484 tons $\mathrm{CO}_{2}$-Eq, while energy indirect emissions are 0,847 tons $\mathrm{CO}_{2}$-Eq. At the internal distribution of scope 1 , emission from natural gas consumption is $54.97 \%$ and 2,465 tons $\mathrm{CO}_{2}$-Eq; emissions from vehicle fuels are $44.43 \%$ and 1,992 tons of $\mathrm{CO}_{2}$-Eq; emissions from gas leakages are $1.82 \%$ and 0.08 tons $\mathrm{CO}_{2}$-Eq. The reason for the biggest emission source of the family is that natural gas is used for heating, hot water supply and cooking. Besides, refrigerant-carrying devices have very low emissions due to their low gas capacity. 


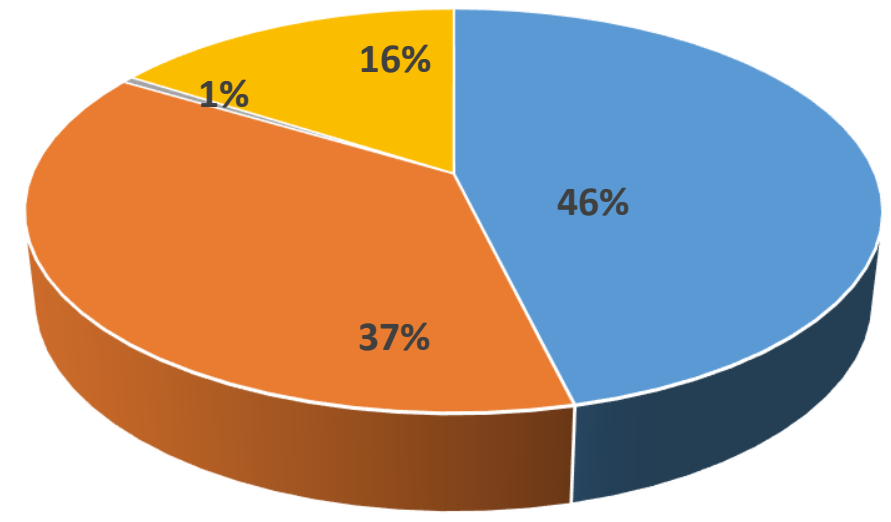

- Scope 1 Natural gas used for heating purposes

- Scope 1 Emissions of vehicles Gasoline

- Scope 1 Refrigerant emissions

- Scope 2 Emissions from electricity

Figure 2. Percentage distribution of GHG emissions

Figure 2 shows the percentages of greenhouse gas sources in total emissions. The ratio of energy indirect emissions to total emissions is $16 \%$. Although all of the devices in a house are electrically operated, electricity is in the third rank among the sources of emissions.

\subsection{GHG Projection Results}

\subsubsection{The projection of GHG reduction}

As the greenhouse gas reduction activities, it is aimed to install the PV system on the roof, replace the conventional central heating boiler with condensing combi boiler and use led lamps instead of incandescent lamps. PVGIS application data is used in PV system installation on the roof. The location of the family and the PVGIS-CMSAF database are selected in PVGIS application. Crystalline silicon is also chosen as PV technology and system losses are assumed as 14\%. In the PV system, two modules with a peak power of $300 \mathrm{Wp}$ are used. The data obtained with the help of PVGIS are given in Table 11 .

Table 11. The average monthly electricity production and sum of global irradiation of the given system

\begin{tabular}{lcc}
\hline Months & Electricity Production $(\mathrm{kWh})$ & Sum of Global Irradiation $(\mathrm{kWh} / \mathrm{m} 2)$ \\
\hline January & 37,4 & 74,5 \\
February & 48,6 & 99,5 \\
March & 66,1 & 139 \\
April & 77,3 & 168 \\
May & 84,3 & 189 \\
June & 86,4 & 199 \\
July & 96,7 & 226 \\
August & 95,6 & 224 \\
September & 84,1 & 192 \\
October & 67,6 & 147 \\
November & 53,8 & 112 \\
December & 37,8 & 76 \\
Total & 835,7 & 1846 \\
\hline
\end{tabular}

In the LED conversion, the 40-watt lamps in the house are replaced with 23 watt led lamps. It is accepted that there are 15 lamps in the house, and three lamps are open in the evening for 5 hours at the same time. As a result of the LED conversion, $93,075 \mathrm{kWh}$ of electricity is saved annually. In projection of another reduction, $24 \mathrm{~kW}$ condensing combi boiler with maximum efficiency of $109 \%$ is used instead of $24 \mathrm{~kW}$ central heating boiler with maximum efficiency of $91 \%$. Thanks to the combi-change, a $16.5 \%$ savings on natural gas is achieved in 2017. As a result, 209,22 sm3 natural gas is saved. 


\subsubsection{The Results of the projection}

With the estimations and calculations, it is examined how and how much a family's greenhouse gas emissions can be reduced. The emission amounts resulting from the projection of reduction are given in Figure 3. Figure 4 presents emission reductions and percentage distributions according to the scope.

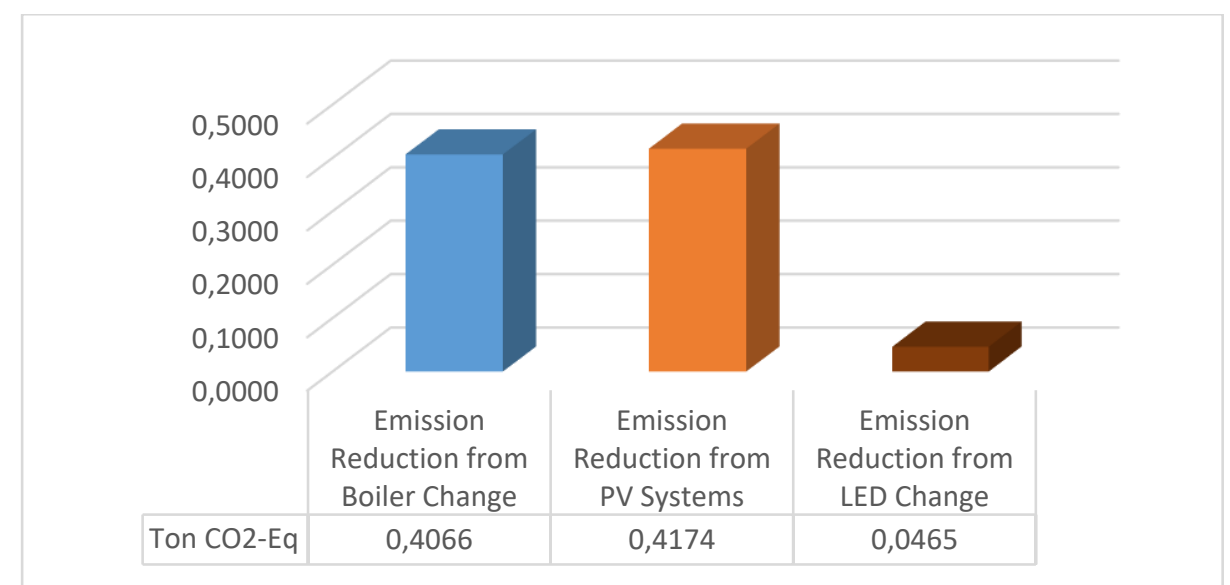

Figure 3. GHG Emission from the projection of reduction (Ton CO2-Eq)

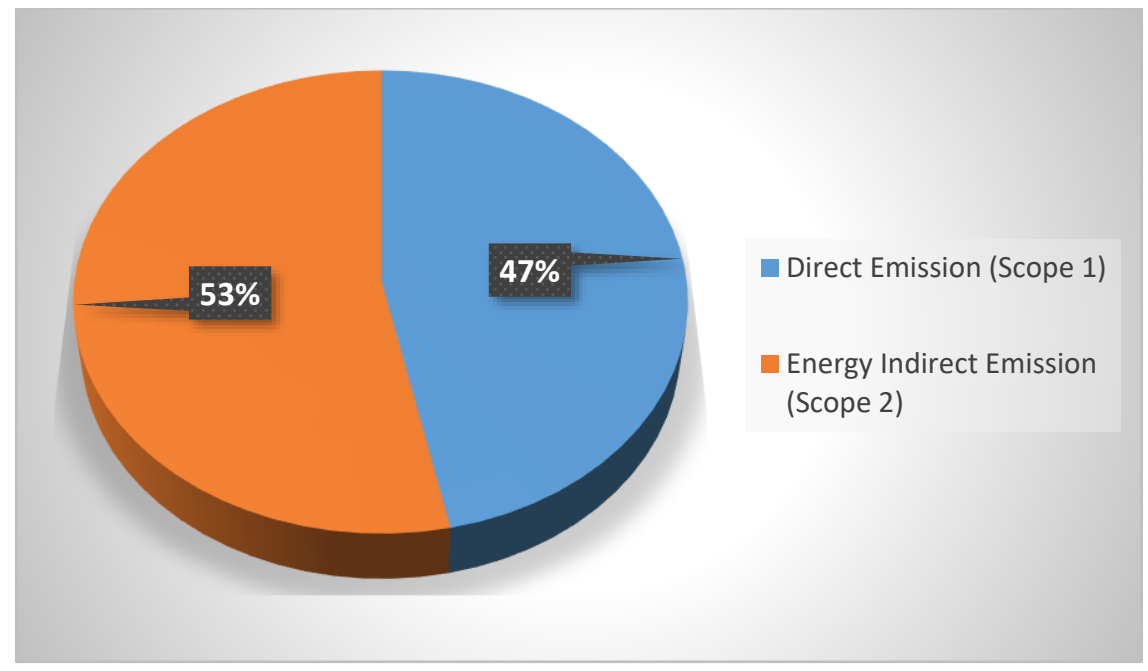

Figure 4. Percentage distributions of emission reduction according to the scope

As a result of projection, it has been predicted that a more efficient boiler can reduce emissions by 0,4066 tons $\mathrm{CO}_{2}$-Eq. Installation PV system on the roof can reduce 0.4174 tons $\mathrm{CO}_{2}$-Eq; while LED bulb conversion can reduce 0.0465 ton $\mathrm{CO}_{2}$-Eq emission (Figure 3). The emission reduction projection is $47 \%$ direct emission and 53\% energy indirect emission in Figure 4.

\subsection{Comparison of Emission Results}

In this study, greenhouse gas emissions of a family are calculated in 2017. As a result of the calculations, the total emission of the family is found to be 5,33 tons $\mathrm{CO}_{2}$-Eq. $84.1 \%$ of the total emission is direct emissions. The remaining $15.9 \%$ is energy indirect emission that is 0,847 tons $\mathrm{CO}_{2}$-Eq. 0,4066 tons $\mathrm{CO}_{2}$-Eq from scope 1 and 0,4639 tons $\mathrm{CO}_{2}$-Eq from scope 2 are reduced in conclusion. 


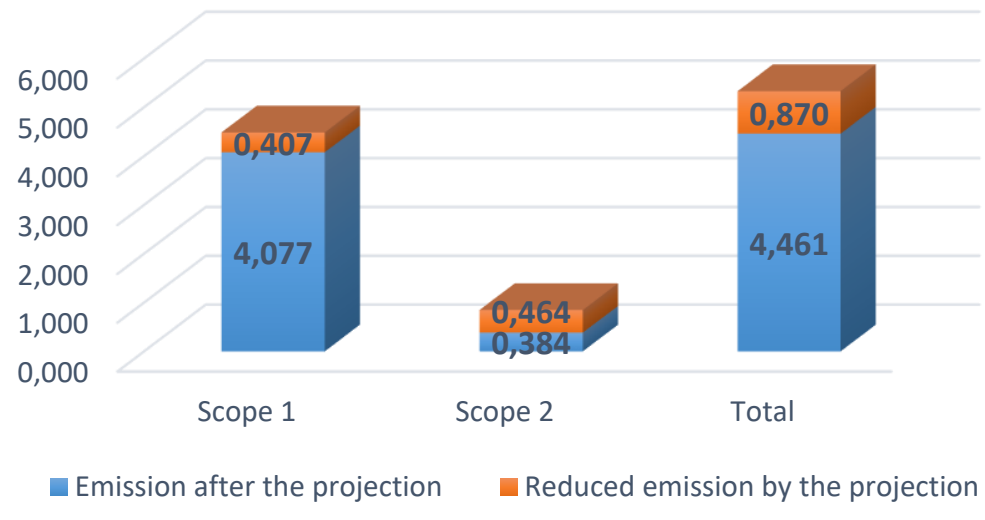

Figure 5. Emission results of the study (tons CO2-Eq)

Consequently, Figure 5 shows that the scope 1 emission is reduced to 4,077 tons $\mathrm{CO}_{2}-\mathrm{Eq}$ and the scope 2 emission is reduced to 0,384 tons $\mathrm{CO}_{2}$-Eq. Moreover, scope 1 emissions are reduced by $10 \%$ while scope 2 emissions are reduced by $120 \%$. Finally, the total emission is reduced by $19.5 \%$.

\subsection{Brief Economic Evaluation}

The economic analysis of the greenhouse gas reduction activities is carried out according to the method of net present value and benefit cost ratio. Some assumptions have been made for the economic analysis. The first one is that the unit price increase rate of $20 \%$ for the second year, $15 \%$ for the third year and $10 \%$ for the other years. The second assumption is that the PV system and boiler are renewed after 15 years. Besides, all the lamps are renewed every 3 years, the last assumption is that the combined interest rate is $15 \%$.

Economic analysis benefit and cost items are listed. First of all, the investment cost of the PV system is $3000 \mathrm{TL}$. Secondly, the scrap price of the previous boiler is $750 \mathrm{TL}$ while the price of the condensed boiler is 2500 TL. Finally, each of the led lamps is 5 TL. In addition, the unit price of electricity unit is $0,331832 \mathrm{TL}$ and the unit price of natural gas is $0,997888 \mathrm{TL}$.

The results obtained from the analysis are given in Figures 5 and 6. Figure 5 shows the results of the net present value method; Figure 6 shows the benefit cost ratio results. Because of the analysis, it is observed that investment of greenhouse gas projection is paid back after 11 years. Besides, the projection make profit after 11 years.

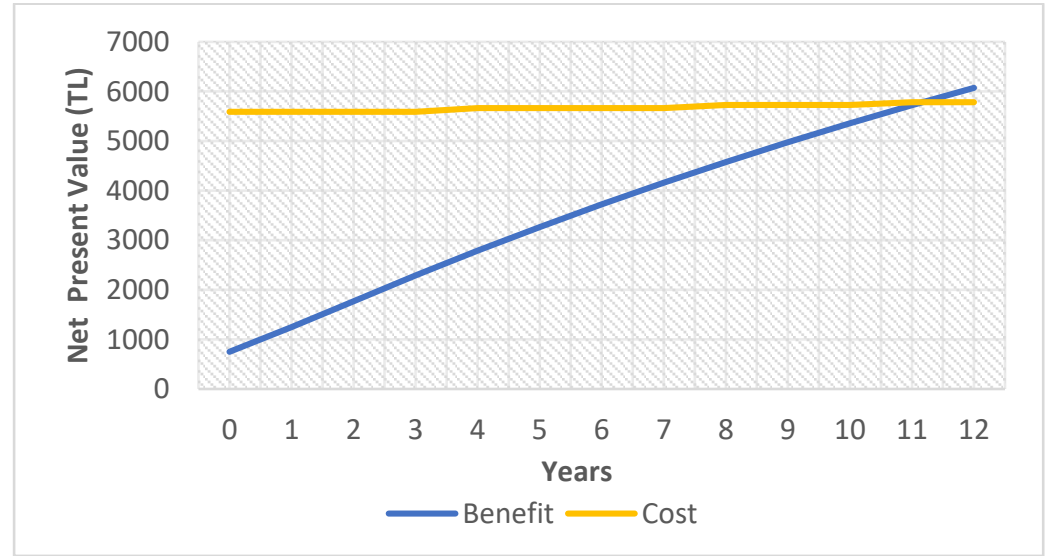

Figure 5. Results of net present value method 


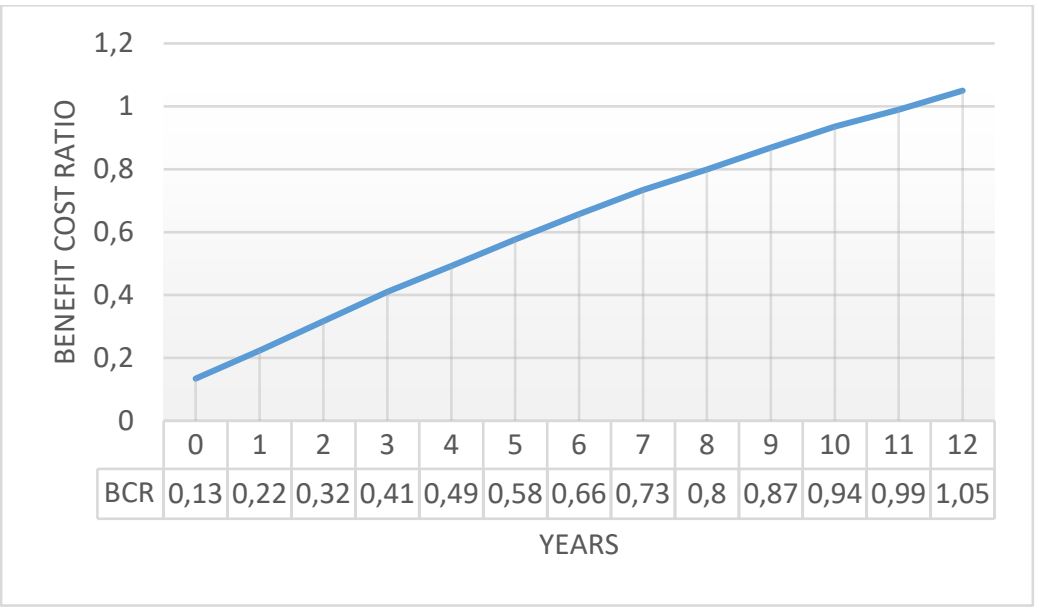

Figure 6. Results of benefit cost ratio method

\section{CONLUSIONS}

In this study, direct and energy indirect emissions of a family in 2017 were calculated. As a result of the calculations, the total emission of the family was found to be 5,331 tons CO2-Eq. In order to decrease the emission, projection calculations were made. In this context, the installation of the PV system, a higher efficiency combine boiler and low energy consumption led bulbs were planned. In the case of realization of projection activities, 0,87 tons of $\mathrm{CO} 2-\mathrm{Eq}$ emission reduction can be carried out. Thus, an emission reduction of about $20 \%$ was found.

Among the targets of Turkey for 2030, $21 \%$ of the total emission reduction is planned. So, renewable energy sources should be used to achieve the planned targets. Moreover, it is seen that European countries have reduced their emissions by measures taken in line with the Kyoto Protocol targets, and this has been achieved through renewable energy sources. For this reason, it is suggested to emphasize energy efficiency and to utilize renewable energy sources in this study.

It is predicted that global climate change effects will increase in the future. It is estimated that climate change will lead to significant consequences such as rising sea level, displacement of climate zones, severe weather events occurring more frequently and effectively, drought-erosion-desertification, increased epidemics, damaging to wildlife species due to deterioration of natural equilibrium and human health deterioration. Therefore, attention should be paid to greenhouse gas emissions and global climate change. Furthermore, everyone should be aware of this topic and take maximum care to protect the environment and climate.

Finally, the study both will guide the calculation of greenhouse gas emissions according to IPCC guidelines and ISO 14064-1 standard and will also help those who wish to reduce greenhouse gas emissions.

\section{REFERENCES}

[1] Serengil, Y. Küresel Isınma ve Olası Ekolojik Sonuçları [Global Warming and Possible Ecological Consequences]. İstanbul Üniversitesi Orman Fakültesi Dergisi,1995, 45(1-2), 135-152. Retrieved from http://dergipark.gov.tr/jffiu/issue/18733/197557 
[2] Türkeş, M. IPCC İklim Değişikliği 2013: Fiziksel Bilim Temeli Politikacılar için Özet Raporundaki Yeni Bulgu ve Sonuçların Bilimsel Bir Değerlendirmesi [IPCC Climate Change 2013: A Scientific Assessment of New Findings and Results in the Summary Report for Political Scientists in Physical Science], İklim Değişikliğinde Son Gelişmeler: IPCC 2013 Raporu Paneli Bildiriler Kitapçığı, İstanbul Politikalar Merkezi, Sabancı Üniversitesi, İstanbul,2013, 8-18.

[3] Davarcıoğlu, B. Küresel İklim Değişikliği ve Uyum Çalışmaları: Türkiye Açısından Değerlendirilmesi [Global Climate Change and Adaptation Activities: Evaluation of Turkey]. Mesleki Bilimler Dergisi,2018, 7(2). Retrieved from http://dergipark.gov.tr/mbd/issue/40281/407992

[4] Bilgiç, E. İklim Değişikliği ile Mücadelede Emisyon Ticareti ve Türkiye Uygulaması [Emissions Trading in Combating Climate Change and Practice of Turkey], Specialist Thesis, Ministry of Environment and Urbanization, Ankara, Turkey,2017, 29-48.

[5] TS EN ISO 14064-1. Greenhouse Gases-Part 1: Specification with guidance at the organization level for quantification and reporting of greenhouse gas emissions and removals. Turkish Standards Institution. Ankara, Turkey, 2007.

[6] TS EN ISO 14064-2. Greenhouse Gases-Part 2: Specification with guidance at the project level for quantification, monitoring and reporting of greenhouse gas emission reductions or removal enhancements. Turkish Standards Institution. Ankara, Turkey, 2007.

[7] TS EN ISO 14064-3. Greenhouse Gases-Part 3: Specification with guidance for the validation and verification of greenhouse gas assertions. Turkish Standards Institution. Ankara, Turkey, 2007.

[8] Turkish Statistical Institute. Sera gazı emisyonları (milyon ton eCO2) [Greenhouse Gas Emission (Million ton CO2-Eq)]. Ankara, 2018. Retrieved May 15, 2019, from http://www.tuik.gov.tr/PreTablo.do?alt_id=1019

[9] Turkish Statistical Institute. Sera Gazı Emisyon İstatistikleri [Greenhouse Gas Emission Statistics], No 27675. Ankara, 2018. Retrieved Mayr 15, 2019, from http://tuik.gov.tr/OncekiHBArama.do

[10] UNFCCC. Republic of Turkey Intended Nationally Determined Controbution, 2015, Ankara, Turkey.

[11] International Energy Agency. World Energy Outlook 2014,2015, IEA, 1-8.

[12] Rico, A., Martínez-Blanco, J., Montlleó, M., Rodríguez, G., Tavares, N., Arias, A., Oliver-Solà, J. Carbon footprint of tourism in Barcelona. Tourism Management,2019, 70, 491-504. doi:10.1016/j.tourman.2018.09.012

[13] Bastianoni, S., Marchi, M., Caro, D., Casprini, P., and Pulselli, F. M. The connection between 2006 IPCC GHG inventory methodology and ISO 14064-1 certification standard - A reference point for the environmental policies at sub-national scale. Environmental Science and Policy,2014, 44, 97-107. doi:10.1016/j.envsci.2014.07.015

[14] Ayalon, O., Lev-On, M., Lev-On, P., Goldrath, T. Greenhouse Gas emissions reporting in Israel: Means to manage energy use. Energy Conversion and Management, 2014, 85, 612-618. doi:10.1016/j.enconman.2014.04.064

[15] Ponstein, H. J., Meyer-Aurich, A., Prochnow, A. Greenhouse gas emissions and mitigation options for German wine production. Journal of Cleaner Production, 2019, 212, 800-809. doi:10.1016/j.jclepro.2018.11.206

[16] Kılıç, E., Puig, R., Zengin, G., Zengin, C. A., Fullana-I-Palmer, P. Corporate carbon footprint for country Climate Change mitigation: A case study of a tannery in Turkey. Science of The Total Environment, 2018, 635, 60-69. doi:10.1016/j.scitotenv.2018.04.111

[17] Babaoğlu, N, Özgünoğlu, K. Kahramanmaraş Havalimanı İçin Uçaklardan Kaynaklanan Emisyonların Belirlenmesi [Determination of Aircraft Emissions at Kahramanmaraş Airport]. Kahramanmaraş Sütçü İmam University Journal of Engineering Sciences, 2017, 20 (3), 24-30. DOI: 10.17780/ksujes.335226

[18] Sangwan, K. S., Bhakar, V., Arora, V., Solanki, P. Measuring Carbon Footprint of an Indian University Using Life Cycle Assessment. Procedia CIRP, 2018, 69, 475-480. doi:10.1016/j.procir.2017.11.111

[19] Marchi, M., Neri, E., Pulselli, F. M., Bastianoni, S. CO2 recovery from wine production: Possible implications on the carbon balance at territorial level. Journal of CO2 Utilization, 2018, 28, 137-144. doi:10.1016/j.jcou.2018.09.021

[20] Marchi, M., Pulselli, F. M., Mangiavacchi, S., Menghetti, F., Marchettini, N., Bastianoni, S. The greenhouse gas inventory as a tool for planning integrated waste management systems: A case study in central Italy. Journal of Cleaner Production,2017, 142, 351-359. doi:10.1016/j.jclepro.2016.05.035

[21] IPCC. In: Eggleston, H.S., Buendia, L., Miwa, K., Ngara, T., Tanabe, K. (Eds.), Guidelines for National Green House Gas Inventories Volume 2 Chapter 2 Stationary Combustion, , IGES, Japan, 2006.

[22] Europen Commission. Photovoltaic Geographical Information System, 2017. Retrieved May 15, 2019, from http://re.jrc.ec.europa.eu/pvg_tools/en/tools.html

[23] Özdemir, M.B.; Yatarkalkmaz, M.M. Energy, Exergy and Economic Analysis of Different Types of Collectors. Gazi Journal of Engineering Sciences ,2015, 1 (2), 235-251. 
[24] IPCC. In: Eggleston, H.S., Buendia, L., Miwa, K., Ngara, T., Tanabe, K. (Eds.), Guidelines for National Green House Gas Inventories Volume 3 Chapter 7 Emission of Flourinated Substitutes for Ozone Depleting Substances, IGES, Japan, 2006.

[25] IPCC. In: Eggleston, H.S., Buendia, L., Miwa, K., Ngara, T., Tanabe, K. (Eds.), Guidelines for National Green House Gas Inventories Volume 2 Chapter 3 Mobile Combustion, IGES, Japan, 2006.

[26] IPCC. In: Stocker, T., Dahe, Q., Plattner, G.K. (Eds.), Climate Change 2013: The Physical Science Basis. Contribution of Working Group I to the 5th Assessment Report of the IPCC. IPCC, Stockholm, 2013.

[27] Turkish Electricity Transmission Company. Producer Organizations Distribution of Fuels Consumed in Thermal Power Plant Turkey (2006-2017), 2018. Retrieved December 25, 2018, from https://www.teias.gov.tr/tr/iv-turkiye-termik-santrallarinda-kullanilan-yakit-miktarlari-isil-degerleri-vekojenerasyon-0

[28] Turkish Electricity Transmission Company. Producer Organizations Heat Value of Distribution of Thermal Power Plant Fuel Used in Turkey (2006-2017), 2018. Retrieved December 25, 2018, from https://www.teias.gov.tr/tr/iv-turkiye-termik-santrallarinda-kullanilan-yakit-miktarlari-isil-degerleri-vekojenerasyon- 0

[29] Turkish Electricity Transmission Company. Turkey Electricity Energy Consumption and Production Development of Annual Loss (1993- 2017), 2018. Retrieved December 25, 2018, from https://www.teias.gov.tr/tr/iii-elektrik-enerjisi-uretimi-tuketimi-kayiplar-0 